\title{
Epidemiological characteristics of a Zika outbreak in Portoviejo, Ecuador, 2016
}

\author{
Martha Fors, ${ }^{1}$ Eduardo Silva, ${ }^{2}$ and Paloma González ${ }^{3}$
}

Suggested citation Fors M, Silva E, González P. Epidemiological characteristics of a Zika outbreak in Portoviejo, Ecuador, 2016. Rev Panam Salud Publica. 2018;42:e68. https://doi.org/10.26633/RPSP.2018.68

ABSTRACT Objective. To estimate the number and percentage of cases with Zika diagnosis at a hospital in Portoviejo, Manabi, Ecuador.

Methods. This was a hospital-based, retrospective, observational, descriptive, cross-sectional study conducted at the Dr. Verdi Cevallos Balda Hospital from January - August 2016. A secondary analysis of a database was performed to estimate the number and percentage of patients positive for Zika virus, by sex, age group, ethnicity, and type of medical care. Prevalence and odds ratios with 95\% Confidence Intervals were calculated using the Mantel and Haenszel method. Laboratory diagnostics included assays for the detection of Zika, chikungunya, dengue, and others.

Results. In all, 467 suspected cases of Zika were identified based on clinical criteria. Of these, 148 cases (31.7\%) were confirmed by detection of ZIKV RNA. The peak of the outbreak was documented in May - July 2016 during the rainy season, following the earthquake of April 2016. The adjusted odds ratios indicated that Zika virus was less likely in men and in subjects $<20$ years of age. Most of the infected pregnant women (61\%) were in the second trimester of pregnancy. No cases of microcephaly were reported.

Conclusions. Because Zika was more likely to occur among women and those $\geq 20$ years of age, surveillance of these groups is imperative to avoid transmission to newborns. Future studies that address the research gap and inform the country's Zika control efforts are recommended.

Keywords Zika virus infection; epidemics, Zika virus; Ecuador.

Zika virus (ZIKV) is an emerging virus transmitted by mosquitoes. It was first identified in Uganda in 1947 during routine monitoring of rhesus monkeys for jungle yellow fever. In 1952, it was identified in humans in Uganda and in the United Republic of Tanzania (1).

The Zika virus belongs to the Flaviviridae family. Other members of this family

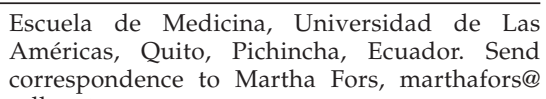
Américas, Quito, Pichincha, Ecuador. Send correspondence to Martha Fors, marthafors@ udlanet.ec are the yellow fever virus, dengue virus, and Japanese encephalitis virus. Ribonucleic acid (RNA) viruses are transmitted by vectors, in this case by Aedes aegypti, A. albopictus (2), and other species of the genus Aedes (3). The Zika virus is characterized as a mild, dengue-like disease with fever, muscle aches, eye pain, prostration, and a maculopapular rash. In more than 60 years of observations, Zika

\footnotetext{
Hospital Dr. Verdi Cevallos Balda, Portoviejo, Manabí, Ecuador.

3 Biblioteca de la Universidad de Las Américas, Quito, Pichincha, Ecuador.
}

has not been known to cause hemorrhagic fever or death (3).

In urban and suburban environments, the Zika virus is transmitted in a humanmosquito-human transmission cycle. The Aedes species is particularly difficult to control because it can reproduce in extremely small amounts of water. A large increase in ZIKV has been observed worldwide, whereas initially, it was endemic only in Africa and Asia. Cases have been reported in Europe, Oceania, and the Americas, particularly in Latin America, where it is rapidly spreading to new areas (4). 
Zika virus infections were first detected in the Western Hemisphere in February 2014 on Chile's Easter Island. Cases were reported in northern Brazil that are suggestive of the presence of Zika in the Americas as early as October 2014, but infections were not detected and confirmed until May 2015 (5).

In January 2018, the Ministry of Public Health of Ecuador (MSP) reported that the total number of cases diagnosed in the country was 5304 for the period from 2015 - 2017. In 2016, in the province of Manabí, the number of cases reached 2509 , representing $85.2 \%$ of the total cases in the country (6). In Ecuador, there is a national strategy for controlling mosquito-borne diseases, with specific measures for reducing Zika cases (7).

Information on the ZIKV epidemic in Ecuador is limited, with few studies published in scientific journals. The MSP has published some information on its website regarding the disease.

The objective of this study was to estimate the number and percentage of cases with a Zika diagnosis at the Dr. Verdi Cevallos Balda Hospital during an outbreak of the disease in Portoviejo, Ecuador, in January - August 2016.

\section{MATERIALS AND METHODS}

A hospital-based, retrospective, observational, descriptive, cross-sectional study was conducted to estimate the number and percentage of patients with Zika infection treated by the Dr. Verdi Cevallos Balda Hospital in Portoviejo, a small town in the province of Manabí, Ecuador. The data was extracted from a national surveillance database created by the MSP to gather information on epidemiological outbreaks. The laboratory of the National Institute of Public Health (a national reference laboratory in Ecuador) was responsible for conducting the molecular tests to confirm ZIKV. This work was reported with the STrengthening the Reporting of OBservational studies in Epidemiology (STROBE) checklist (8).

\section{Patients and study design}

A search was conducted of a database with information on patients treated in January - August 2016 by the Dr. Verdi Cevallos Balda Hospital, the only public health system hospital in Portoviejo. The database included all patients who were treated at the hospital, regardless of age, sex, or other conditions, with symptoms related to contagious diseases; thus, there were no exclusion criteria. The case definition for this infection included one or more of the following symptoms: nonpurulent conjunctivitis, headache, pruritus, or arthralgia. For this analysis, cases included all patients who were reported to MSP with symptoms of ZIKV, with or without laboratory confirmation. Laboratory-confirmation was defined as the presence of clinical symptoms of Zika and a sample reactive by real-time reverse transcription polymerase chain reaction (rRT-PCR assay).

Ethics. Authorization to obtain the data and to carry out this study was granted by the Ethics Committee of the Dr. Verdi Cevallos Balda Hospital. The study used a de-identified dataset to protect the confidentiality of the subjects.

\section{Statistical analysis}

Categorical variables were expressed as counts and percentages, while continuous variables were presented as mean \pm standard deviation (SD). The number of cases according to sex, age group, ethnicity, and type of medical care were analyzed. The number of pregnant women with Zika was calculated according to pregnancy trimester. The prevalence ratio was calculated with a 95\% Confidence Interval (95\%CI). The adjusted odds ratios (aORs) and $95 \%$ CIs were calculated using MantelHaenszel for associations of age, sex, and ethnicity (independent variables). For this calculation, the age variable was

\section{FIGURE 1. Evolution over time of the number of suspected cases of Zika in Portoviejo, Ecuador, January - August 2016}

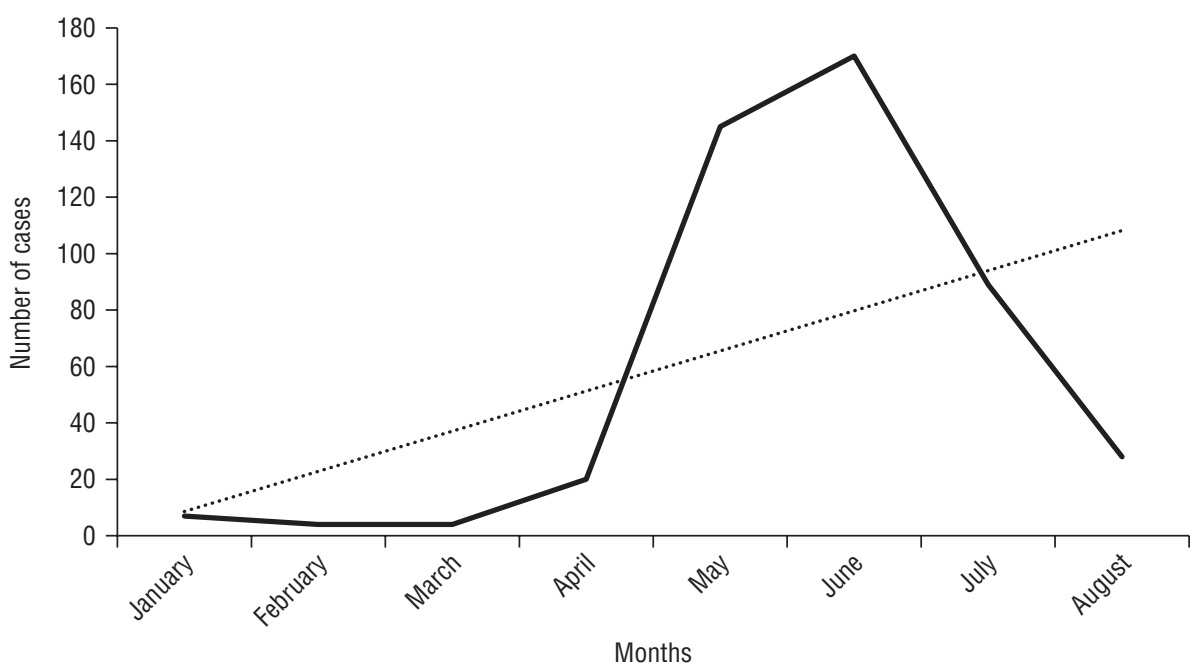

Source: Prepared by the authors from the study results. separated into two categories: $<20$ years of age and $\geq 20$ years, taking into account that most suspected cases were among those $\geq 20$. Additionally, ethnicity was grouped into two categories: mixed race (the country's main ethnic group comprised of European, Indigenous, Middle-Eastern, Asian and/or African ancestry) and other. For assessing the association between variables, Fisher's exact or chi-square tests were used. To compare the quantitative variables, the Student's T-test was used with the significance level fixed at 5\%. Statistical analyses were performed using IBM SPSS Statistics software, version 24 (SPSS Inc., an IBM company, Chicago, Illinois, United States).

\section{RESULTS}

From 1 January 2016 - 31 August 2016, a total of 776 patients were treated by the hospital in Portoviejo, 96.3\% of whom were from Portoviejo; the remainder was from districts near the city. Of the total, $467(60.2 \%)$ were suspected cases of ZIKV disease, based on the presence of an acute onset rash with or without fever. Of the suspected cases, 148 (31.7\%) were confirmed by the detection of ZIKV RNA through rRT-PCR. The rest of the subjects were diagnosed with dengue, chikungunya, or influenza, among other illnesses.

Figure 1 shows the evolution over time of the number of cases with an initial Zika diagnosis during the study period. An increase in Zika cases was observed from the first month of the study (January) to 
the last (August). The number of cases began to rise in April, with May and June seeing the highest numbers. A decrease was then observed from June through the end of the study period.

The majority of the included subjects were female $(65.1 \%)$, and of these, only $35.2 \%$ had a laboratory confirmation of Zika; while for men, confirmation was $25.2 \%$. Among patients with PCR reactive for Zika, women accounted for the majority.

Most of the patients were $20-49$ years of age $(65.5 \%)$, followed by the group $15-19$ years of age. The initial diagnosis of Zika was less frequent in those $\geq 65$ years. Regarding ethnicity, $99.9 \%$ of positive cases of Zika were within the mixed race group. Most patients affected by Zika were treated on an outpatient basis; only two patients required hospitalization. The group with other diagnoses exhibited similar behavior, but their PCR was non-reactive to ZIKV (Table 1).

A significant association was found between gender and age and ZIKV $(P<$ $5 \%$ ). A higher proportion of female subjects was found to have a reactive PCR for Zika. With respect to age range, patients $20-49$ years and $50-64$ years were associated with positive cases of the virus. The frequency of patients according to ethnic group and type of care was similar between the two groups, with no association found $(P \geq 0.05)$.

The mean age of the 148 confirmed patients was 30 years \pm 15 years, while the median age was 28, and the mode, 29 years. For those with a non-reactive PCR for Zika, the mean age was 25.5 years \pm 16.7. The difference was statistically significant (Student's T test $P=0.00$ ).

The associations between the independent variables and ZIKV are presented in Table 2. It was observed that the prevalence of Zika in women was higher than in men and higher among those $\geq 20$ years of age. All the variables (gender, age, and ethnicity) in the model were significantly associated with Zika. Men were less likely to have the virus than women were $(\mathrm{a} 0 \mathrm{R}=0.62)$, and those $<20$ years of age appeared to be protected against the virus $(\mathrm{a} 0 \mathrm{R}=0.43)$. In both cases, $P$ values were $<0.05$.

An average of 3.3 days ( \pm 0.98 days) passed from the onset of symptoms to the date of being treated at the hospital. Three patients were excluded from the analysis as outliers at 12,15 , and 26 days. The main

TABLE 1. Patients according to polymerase chain reaction (PCR) results for Zika and their main baseline characteristics, Portoviejo, Ecuador, January - August 2016

\begin{tabular}{|c|c|c|c|c|c|c|}
\hline \multirow{3}{*}{ Patient characteristics } & \multicolumn{4}{|c|}{ PCR for Zika } & \multirow{3}{*}{$\begin{array}{c}\text { Total } \\
\text { No. }\end{array}$} & \multirow{3}{*}{$P$ value $^{\mathrm{a}}$} \\
\hline & \multicolumn{2}{|c|}{$\begin{array}{l}\text { Reactive } \\
n=148 \\
(31.7 \%)\end{array}$} & \multicolumn{2}{|c|}{$\begin{array}{c}\text { Non-reactive } \\
n=319 \\
(68.3 \%)\end{array}$} & & \\
\hline & No. & $\%$ & No. & $\%$ & & \\
\hline \multicolumn{7}{|l|}{ Gender } \\
\hline Male & 41 & 27.7 & 122 & 38.2 & 163 & 0.0163 \\
\hline Female & 107 & 72.3 & 197 & 61.8 & 304 & \\
\hline \multicolumn{7}{|l|}{ Group by age, in years } \\
\hline$<1$ & 2 & 1.4 & 15 & 4.7 & 17 & \\
\hline $1-4$ & 5 & 3.4 & 34 & 10.7 & 39 & \\
\hline $5-9$ & 8 & 5.4 & 31 & 9.7 & 39 & 0.0063 \\
\hline $10-14$ & 5 & 3.4 & 23 & 7.2 & 28 & \\
\hline $15-19$ & 15 & 10.1 & 30 & 9.4 & 45 & \\
\hline $20-49$ & 97 & 65.5 & 163 & 51.1 & 260 & \\
\hline $50-64$ & 12 & 8.1 & 17 & 5.3 & 29 & \\
\hline$\geq 65$ & 4 & 2.7 & 6 & 1.9 & 10 & \\
\hline \multicolumn{7}{|l|}{ Ethnicity } \\
\hline Indigenous & 2 & 1.4 & 1 & 0.3 & 3 & 0.1689 \\
\hline Mixed race & 140 & 94.6 & 313 & 98.1 & 453 & \\
\hline Not available & 6 & 4.1 & 5 & 1.6 & 11 & \\
\hline \multicolumn{7}{|l|}{ Type of care } \\
\hline Outpatients & 146 & 98.6 & 310 & 97.1 & 456 & 0.1785 \\
\hline Hospitalized & 2 & 1.4 & 9 & 2.9 & 11 & \\
\hline
\end{tabular}

${ }^{a}$ Chi square test for association (two tails).

Source: Prepared by the authors from the study results. symptoms were elevated body temperature, maculopapular rash that often extended from the face to the body, arthritis or arthralgia with transient inflammation of joints (especially in the small joints of the hands and feet), and conjunctival hyperemia. Other non-specific symptoms, such as myalgia, fatigue, and headache were also common. None of the patients had a vaccination history or known comorbidities. It should also be noted that all the cases studied were autochthonous.

The duration of symptoms ranged from $2-7$ days, with a mean of 4.5 days $( \pm 1.8$ days). No deaths or neurologic complications following the Zika virus infection occurred among the patients studied.

Of the 265 women of childbearing age (15 - 49 years), 110 were pregnant; of these, only 33 had a confirmation of Zika by PCR. Of the 33 pregnant women with Zika, $61 \%$ were in their second trimester, while $39 \%$ were in the first. At the time of this report, most of these pregnancies were still ongoing. There was a nonsignificant statistical association between the age of the pregnant woman and the virus (Table 3 ).

\section{DISCUSSION}

This study is the first to report data concerning the percentage of positive cases of Zika in a hospital in the city of Portoviejo, Ecuador. Of the suspected cases, $31.7 \%$ were positive for ZIKV as confirmed by PCR.

The peak number of ZIKV cases was observed in June 2016 during the rainy season, concurring with the weather patterns found in previous outbreaks in Brazil (9). In the Portoviejo area, the rainy season runs from December to mid-May, but heavy rains may occur frequently throughout the year. The proliferation of stagnant water, plus the impact of the earthquake that occurred along the Pacific coast in Ecuador on 16 April 2016, increased the risk of vector transmission, possibly causing the rise in Zika cases. In 2017, the percentage of cases decreased dramatically in the same area, from $85.2 \%$ to $35.4 \%$ (6).

The study results showed that men were less likely to get Zika than women, as were people under 20 years of age. A study conducted in Brazil by Coelho and colleagues demonstrated that the incidence of Zika is higher among women and those 15 - 65 years age (10). In another study performed in Brazil, the age distribution of confirmed ZIKV cases 
TABLE 2. Association between the independent variables of the study (gender, age, and ethnicity) and the Zika virus, Portoviejo, Ecuador, January - August 2016

\begin{tabular}{lcccccc}
\hline $\begin{array}{l}\text { Predictive } \\
\text { factors }\end{array}$ & $\begin{array}{c}\text { Adjusted } \\
\text { prevalence ratio }\end{array}$ & $\begin{array}{c}95 \% \text { Confidence } \\
\text { Interval }\end{array}$ & $P$ value & $\begin{array}{c}\text { Adjusted odds } \\
\text { ratio }\end{array}$ & $\begin{array}{c}95 \% \text { Confidence } \\
\text { Interval }\end{array}$ & $P$ value $^{\mathrm{a}}$ \\
\hline $\begin{array}{l}\text { Gender } \\
\text { Female }\end{array}$ & Ref & Ref & Ref & Ref & Ref & Ref \\
$\quad \begin{array}{l}\text { Male } \\
\text { Age }\end{array}$ & 0.72 & $0.54-0.97$ & 0.0312 & 0.62 & $0.40-0.95$ & 0.0263 \\
$\quad<20$ years & Ref & Ref & Ref & Ref & Ref & Ref \\
$\quad \begin{array}{l}20 \text { years } \\
\text { Ethnicity }\end{array}$ & 0.66 & $0.47-0.91$ & 0.0118 & 0.43 & $0.26-0.67$ & 0.0126 \\
$\quad \begin{array}{l}\text { Mixed race } \\
\text { Other }\end{array}$ & Ref & Ref & Ref & Ref & Ref & Ref \\
\hline
\end{tabular}

a Mantel-Haenszel test.

Source: Prepared by the authors from the study results.

TABLE 3. Pregnant women according to age group and results of to polymerase chain reaction (PCR), Portoviejo, Ecuador, January - August 2016

\begin{tabular}{|c|c|c|c|c|c|c|c|}
\hline \multirow{2}{*}{ Age group } & \multicolumn{2}{|c|}{ PCR reactive } & \multicolumn{2}{|c|}{ PCR non-reactive } & \multicolumn{2}{|c|}{ Total } & \multirow[t]{2}{*}{$P$ value $^{\mathrm{a}}$} \\
\hline & $n$ & $\%$ & $n$ & $\%$ & $n$ & $\%$ & \\
\hline $15-19$ years & 8 & 36.0 & 14 & 64.0 & 22 & 20.0 & \\
\hline $20-49$ years & 25 & 28.4 & 63 & 71.6 & 88 & 80.0 & 0.60 \\
\hline Total & 33 & 30.0 & 77 & 70.0 & 110 & 100.0 & \\
\hline
\end{tabular}

a Fisher exact test.

Source: Prepared by the authors from the study results.

suggested a higher proportion of cases in individuals from 20 - 50 years of age (9), a pattern very similar to the one observed by our study.

Zika virus usually presents with mild symptoms that may go unnoticed or be misdiagnosed as dengue, chikungunya, or other viral diseases that cause fever and rash. These diseases are also common in Manabí, which is why the percentage of patients with other diagnoses in our study was very high. In most cases, symptoms were treated and very few hospitalizations were required.

According to a study of Zika in pregnancy (11), pregnant women do not differ from other population groups in terms of the frequency of complications. However, the virus has a high affinity for nerve tissue, so the central and peripheral nervous systems of both mother and fetus can be compromised to varying degrees, depending on viral virulence, viral load, susceptibility, and personal immune response (11). The results of our study are consistent with this statement.

Due to the high number of pregnant women in our study, the hospital has established a system of close monitoring for these pregnancies. Fetal abnormalities have been reported in pregnant women with the Zika (12), but at the time of this study, the hospital's epidemiology department had not reported any cases of microcephaly or other adverse neonatal outcomes. However, for the period 2015 2017, there were four cases of microcephaly reported in Manabí (6), probably occurring after our study period. Zambrano and colleagues reported two cases of microcephaly linked to ZIKV in Guayaquil, a city located in another province of Ecuador (13).

A case control study performed in coastal Ecuador (14), including Manabí, reported that the incidence of ZIKV among the general population and in pregnant women rose after the earthquake of April 2016. At the national level, in 2015 - 2017, Ecuador reported 959 cases of Zika in pregnant women: 134 cases in pregnant women with a gestational age of $<12$ weeks, 417 cases with a gestational age $\geq 12$ weeks, and 166 cases with a gestational age $\geq 28$ weeks (6). In 2016, there were 242 reported cases of Zika among pregnant women in all of Ecuador.

This study corroborates previously published reports suggesting that the clinical course of the Zika virus is typically mild in adults (15).

Limitations. This study is the first to report data on Zika prevalence in the city of Portoviejo, Ecuador. It is limited to one particular situation in a single hospital in just one city; it does not reflect the reality of the entire country. The study design would have been stronger if it had been integrated with a simultaneous entomological survey of the study area. Another limitation is that the study used secondary data, which may not be accurate. Also, the data were not collected to answer a research question, but rather as part of the MSP surveillance system.

\section{Conclusions}

This work was the first to investigate the characteristics of the Zika epidemic in Portoviejo; it reviews some data about epidemiological characteristics of the disease and possible associations with risk factors. The percentage of confirmed cases reached one-third of the study population. The disease was more likely to occur in women and in subjects over 20 years of age, stressing the importance of surveillance of this group to avoid transmission of Zika to newborns. The number of infected pregnant women was an important finding that could be used as an indicator to help determine the risk of complications from Zika in infants.

Authorities at the hospital and the Ministry of Public Health are working hard to diminish the high number of suspected cases of Zika and are giving special attention to pregnant women. However, there are still many questions to be answered in relation to the presence of Zika virus in Ecuador. Future studies are recommended for addressing the research gap and to inform national Zika control efforts.

Acknowledgements. The authors would like to thank Mrs. Stephanie Gabela for her assistance in reviewing the English language of the paper and her comments on an early version of the manuscript.

Funding. The Ministry of Health of Ecuador provided funding for this study, but had no role in the study design, data collection or analysis, decision to publish, or preparation of the manuscript.

\section{Conflicts of interest: None declared.}

Disclaimer. Authors hold sole responsibility for the views expressed in the manuscript, which may not necessarily reflect the opinion or policy of the RPSP/ PAJPH and/or PAHO. 


\section{REFERENCES}

1. Dick GW, Kitchen SF, Haddow AJ. Zika virus I: isolations and serological specificity. Trans R Soc Trop Med Hyg. 1952;46:509-20. doi: 10.1016/0035-9203(52) 90042-4

2. Perret C. Virus Zika, ¿culpable o inocente? Rev Chil Infectol. 2016;33(2):189-90. Available from: www.scielo.cl/scielo.php?script= sci_arttext\&pid=S0716-10182016000200008 \&lng=es Accessed 13 March 2018.

3. Fauci AS, Morens DM. Zika virus in the Americas-yet another Arbovirus threat. N Engl J Med. 2016;374:601-4. doi: 10.1056/ NEJMp1600297

4. Zanluca C, de Melo VC, Mosimann AL, Dos Santos GI, Dos Santos CN, Luz, K. First report of autochthonous transmission of Zika virus in Brazil. Mem Inst Oswaldo Cruz. 2015;110:569-72.

5. Hayes EB. Zika virus outside Africa. Emerg Infect Dis. 2009;15(9):1347-50.

6. Ministry of Health of Ecuador. Enfermedades transmitidas por vectores. Zika semana epidemiológica 01-52/2017. Available from: www.salud.gob.ec/wp-content/ uploads/2015/12/vvGACETA-ZIKA_SE52.pdf Accessed 10 January 2018.

7. Ministry of Health of Ecuador. Respuesta frente a la enfermedad del virus de Zika en el Ecuador. Available from: http://instituciones.msp.gob.ec/images / Documentos/Zika/Lineamientos/PLAN\%20
RESPUESTA\%20DE\%20ZIKA\%202016. pdf Accessed 14 July 2017.

8. von Elm E, Altman DG, Egger M, Pocock SJ Gøtzsche PC, Vandenbroucke JP; STROBE Initiative. The Strengthening the Reporting of Observational Studies in Epidemiology (STROBE) statement: guidelines for reporting observational studies. J Clin Epidemiol. 2008;61(4):344-9.

9. Brasil P, Calvet GA, Siqueira AM, Wakimoto M, de Sequeira PC, Nobre A, et al. Zika virus outbreak in Rio de Janeiro, Brazil: clinical characterization, epidemiological and virological aspects. PLoS Negl Trop Dis. 2016;10(4):e0004636. doi: 10.1371/journal.pntd.0004636

10. Coelho FC, Durovni B, Saraceni V, Lemos C, Codeco CT, Camargo S, et al. Higher incidence of Zika in adult women than adult men in Rio de Janeiro suggests a significant contribution of sexual transmission from men to women. Int J Infect Dis. 2016;51: 128-32. doi: 10.1016/j.ijid.2016.08.023

11. Hernández PE. Infección por Virus Zika en el embarazo. Salus. 2016;20(1):2-57. Available from: www.scielo.org.ve/scielo. php? script $=$ sci_arttext\&pid $=S 1316$ 71382016000100009\&lng=es Accessed 13 March 2018.

12. Honein MA, Dawson AL, Petersen EE Jones AM, Lee EH, Yazdy MM, et al. Birth defects among fetuses and infants of US women with evidence of possible Zika virus infection during pregnancy. JAMA. 2017;317(1):59-68. doi:10.1001/jama.2016. 19006

13. Zambrano H, Waggoner J, León K, Pinsky B, Vera K, Schettino M, et al. High incidence of Zika virus infection detected in plasma and cervical cytology specimens from pregnant women in Guayaquil, Ecuador. Am J Reprod Immunol. 2017;77(2). doi: 10.1111 /aji.12630

14. Vasquez D, Palacio A, Nuñez J, Briones W, Beier JC, Pareja DC, Tamariz L. Impact of the 2016 Ecuador earthquake on Zika virus cases. Am J Public Health. 2017;107(7): 1137-42. doi: 10.2105/AJPH.2017.303769

15. Karwowski MP, Nelson JM, Staples JE, Fischer M, Fleming-Dutra KE, Villanueva J et al. Zika virus disease: a CDC update for pediatric health care providers. Pediatrics. 2016;137(5). Available from: http://pediatrics.aappublications.org / content / 137/5/e20160621.long Accessed 13 March 2018.

Manuscript received on 11 August 2017. Accepted for publication on 14 December 2017.
RESUMEN

Características epidemiológicas de un brote de infección por el virus del Zika en Portoviejo, Ecuador, en el 2016

\author{
Palabras clave
}

Objetivo. Estimar el número y porcentaje de casos con diagnóstico de infección por el virus del Zika en un hospital de Puertoviejo (Manabí, Ecuador).

Métodos. Este fue un estudio retrospectivo basado en un hospital, transversal, descriptivo, de observación, realizado en el Hospital Dr. Verdi Cevallos Balda entre enero y agosto del 2016. Se llevó a cabo un análisis secundario de una base de datos para estimar el número y porcentaje de pacientes positivos para el virus del Zika por sexo, grupo etario, etnicidad y tipo de atención médica. Se calcularon la prevalencia y la razón de posibilidades, con intervalos de confianza de $95 \%$, por el método de Mantel y Haenszel. Los métodos diagnósticos de laboratorio incluyeron análisis para la detección de los virus del Zika, el chikunguña y el dengue, entre otros.

Resultados. En total, se detectaron 467 casos presuntos de infección por el virus del Zika con base en criterios clínicos. De ellos, 148 casos $(31,7 \%)$ se confirmaron por detección de ARN del virus. El punto máximo del brote se documentó entre mayo y julio del 2016, durante la temporada de lluvias, después del terremoto de abril del 2016. La razón de posibilidades no ajustada indicó que fue menos probable la infección por el virus del Zika en los hombres y en las personas menores de 20 años. La mayoría de las embarazadas infectadas (61\%) estaban en el segundo trimestre del embarazo. No se notificaron casos de microcefalia.

Conclusiones. Dado que fue más probable la infección por el virus del Zika en las mujeres y las personas de 20 años en adelante, es indispensable la vigilancia de estos grupos para prevenir la transmisión a los recién nacidos. Se recomiendan estudios ulteriores que subsanen las deficiencias en la investigación y den sustento a las medidas de control del virus del Zika en el país.

Infección por el virus Zika; epidemias, virus Zika; Ecuador. 
RESUMO

\section{Características} epidemiológicas de um surto de zika em Portoviejo, Equador, 2016

Palavras-chave
Objetivo. Estimar o número e o percentual de casos diagnosticados com vírus zika em um hospital em Portoviejo, Manabí, Equador.

Métodos. Estudo observacional transversal descritivo e retrospectivo sediado em um hospital (Hospital Dr. Verdi Cevallo Balda) conduzido de janeiro a agosto de 2016 na cidade de Portoviejo (Manabí), no Equador. Foi realizada uma análise secundária de uma base de dados para estimar o número e o percentual de casos de pacientes infectados pelo vírus zika, desagregada por sexo, faixa etária, grupo étnico e tipo de atenção médica prestada. A prevalência e as razões de chances, com os respectivos intervalos de confiança de $95 \%$, foram calculados com o uso do método de Mantel e Haenszel. Os exames de diagnóstico laboratorial incluíram ensaios para a detecção dos vírus zika, chikungunya e dengue, entre outros.

Resultados. Ao todo, 467 casos suspeitos de zika foram identificados segundo critérios clínicos. Destes, 148 casos (31,7\%) foram confirmados com a detecção do RNA do vírus. Documentou-se a ocorrência do pico do surto entre maio e julho de 2016 durante a estação de chuvas, após o terremoto ocorrido em abril daquele ano. As razões de chances ajustadas indicaram menor probabilidade de infeção no sexo masculino e em indivíduos com idade inferior a 20 anos. A maioria das gestantes infectadas $(61 \%)$ estava no segundo trimestre de gestação. Nenhum caso de microcefalia foi notificado. Conclusões. Visto que se verificou uma maior probabilidade de ocorrência de zika no sexo feminino e em indivíduos com idade acima de 20 anos, é imprescindível a vigilância desses grupos a fim de prevenir a transmissão aos recém-nascidos. Recomenda-se realizar outros estudos para contemplar a lacuna de pesquisa e subsidiar os esforços de controle da zika no país.

Infecção pelo Zika virus; epidemias, Zika virus; Ecuador. 